\title{
New Forms of Democracy in Latvia ${ }^{1}$
}

\section{Rasma Kārkliņa}

Faculty of Humanities,

University of Latvia

Visvalža $4 a$

Riga LV-1050, Latvia

E-mail: rasma.karklina@lu.lv

Abstract: Based on in-depth research, this paper focuses on new forms of selfgovernance and democratic participation in contemporary Latvia. It finds that the theoretical notions of deliberative democracy can be tested by examining the practices of how social groups participate in policy decisions on various levels of government. Under the sponsorship of the European Union and other external supporters, Latvia has developed formal mechanisms of popular participation in governance decisions. This paper analyzes how this works in theory and in practice. On the municipal level nongovernmental groups participate in deliberations about development strategies and discussions about how specific developmental projects might affect their environment. Local NGOs form one of three partners in formalized "partnerships" with local businesses and municipal councils. This participatory involvement suggests that one can speak of a nascent "partnership democracy" in Latvia, and possibly other EU-influenced post-communist states. In Latvia's case, the recent tendency towards the involvement of "social partners" and the forming of partnerships and consultative councils in ministries, municipal councils, and other institutions, fits this category rather well.

Keywords: deliberative democracy, open governance, partnerships, social dialogue

1 This research has been supported by the project "Changing development strategies and cultural spaces of Latvia's rural inhabitants," sponsored by the European Social Fund grant no. 2009/0222/1DP/1.1.1.2.0/09/APIA/VIAA/087 


\section{Introduction}

In many parts of the world scholars have noted a certain fatigue and disenchantment with traditional representative democracy and there have been various initiatives designed to "democratize" democracy (Norris, 1999). Some of these initiatives focus on improving representative democracy by opening government meetings to media and society and asking for more accountability by creating new institutions, for example ombudsman or anti-corruption bureaus. Other attempts focus on formalized citizen initiatives and various types of referenda. In essence, these institutional initiatives emphasize the development of new forms of political participation whereby individuals, groups of citizens, and civic organizations take part in deliberations side by side with governmental decision-makers (Yaojun \& Marsh, 2008, p. 247). Some of these new forms of participation emphasize opening government to active individuals; others emphasize organized groups, especially nongovernmental organizations. This article will focus on the latter, that is the involvement of organized community groups in policy-making. Here the main recent emphasis has been on developing influence through horizontal interaction between different societal groupings, specifically between NGOs and official political players such as political parties and governmental institutions (Petrova \& Tarrow, 2007, p. 79).

There are several theoretical assumptions that this article-as well as the new forms of participation outlined here-are based upon. The first is that the characteristics of institutions and procedures matter, since they provide the structural framework for decision-making. Specifically, the argument is that horizontal deliberations, such as, for example, discussions between partners who are on a basically equal level, are crucial. The quality of deliberation is important as well, and advocates of this approach outline specific procedural and qualitative characteristics that any social dialogue should have.

The second basic assumption underlying this approach is that intense deliberations with citizen organizations are the way to arrive at the best solutions about what policies to pursue in a specific environment, and that this approach helps achieve policy outcomes that satisfy more constituents. This means that all stages of policy-making, including implementation, will be more successful if they are based on citizen involvement. As the repertoire of citizen participation is broadening, the quality of governance should improve. 


\section{Overall levels of political participation in Latvia}

Although our focus is on forms of societal group participation in decision-making, one should note that overall civic participation in Latvia has differed greatly during several distinct phases. During the first phase (1987-1991) of transition from the Soviet system, grassroots social movements and unprecedented mass mobilization were instrumental in triggering the collapse of the Soviet regime and restoring Latvia as an independent state. Societal civic activism during the "Singing Revolution" of 1988-1991 was extremely high, involving huge numbers of participants in demonstrations, petition-signing, a referendum, and elections. Next to mass mobilization there was unprecedented self-organization at the small group and grassroots level, involving too many types of activities than can be mentioned here (Karklins, 1994; Beissinger, 2002).

Once the new democratic system was established, popular participation normalized in 1992 and slowly turned into a more complex phase in the late 1990s that has been marked by partly contradictory types of participation occurring parallel to each other. Next to continuing "normal" participation, such as voting and associational membership, subgroups of disenchanted citizens have increasingly begun to engage in referenda, protests, and illicit ways to influence politics (Karklins \& Zepa, 2001, p. 334). The latter involve corrupt practices, non-payment of taxes, and small-scale resistance to bureaucratic requirements. Other people develop a lifestyle of deliberate non-interaction with the state and its institutions, creating their own "islands" of social autonomy (Sedlenieks, 2012, pp. 88-117; Greenberg, 2010, pp. 41-64). While interesting, it is beyond the limits of the present analysis to discuss these aspects of citizen activity. The focus here is on communal group involvement in policy-making, which is the opposite of deliberate attempts to avoid contacts and keep one's distance from the state and its administration. Popular involvement in politics is based on the assumption that it leads to better policies for all concerned.

\section{Rationales for citizen participation in decision-making}

Several recent analyses sponsored by the European Union have concluded that the concept of participatory citizenship is understood differently across various European countries, and that there is little coherence in policies and practices. The conceptual understanding of the value of participation often is fluid within a country, and it tends to change across time and between different actors (Hoskins 
et al., 2012, p. 18). Nevertheless, the reports emphasize that cooperative arrangements on a group level are very promising, and that collaboration is a key feature of many of the good practice examples of policy-making that have emerged across Europe. These practices highlight the crucial role of forming horizontal and vertical partnership between different institutions: local government, national government, schools, universities, youth councils, nongovernmental organizations, local and international companies, trade unions, arts and cultural organizations and the media. Collaboration enables innovation, the pooling of resources and the sharing of expertise (Krek et al., 2012, p. 31).

Next to cooperation, open government and collaborative decision-making have emerged as key concepts in contemporary policy-making, since "modern government is no longer seen to be effective in formulating and implementing public policies on its own" (Mžavanadze, 2009, p. 397). This dictum has been accepted by Latvia's government, which in 2008 approved a document outlining the basic principles of how state officials should organize their work to improve administrative practices during the period 2008-2013. The document emphasizes the duty of administrators to carefully listen to what society has to say about its problems, to consult it about possible solutions and to inform it about all planned and envisioned action, especially in regard to those persons who may be affected by these policies and activities (Rieksta, 2010, p. 24).

In Latvia and elsewhere, the cooptation of societal institutions in policy-making is seen to lead to better decisions and better governmental policy implementation, with its concrete rationale having been formulated in various ways. Since this paper highlights developments at the municipal level, it is helpful to summarize the pro-participation arguments outlined in a handbook distributed to all municipal councils in Latvia, and especially aimed at officials in the countryside. The handbook argues that the effectiveness of municipal work is dependent on how well officials succeed in continuously communicating with local people on an equal partner basis, thus gaining their trust.

Specifically, the handbook for municipal officials states that "it is important that the local government talk with its inhabitants during all cycles of its policy making" (bold emphasis in the original; LPS, 2009, p. 35). Five such phases are outlined:

1) Identifying what the problem is that needs to be addressed-who needs assistance, and in what way;

2) Designing an appropriate policy_if local people participate in deliberations, they will view the outcome as their own solution and will implement it willingly; 
3) Deciding on a policy or project - if the decision is made with the involvement of local inhabitants this is more likely to be a policy that will work, it will not be a project that local people reject and therefore undermine;

4) Implementing the new policy is much more likely to succeed if it is made easy to comply with. It is effective to not only punish people for noncompliance (using "the stick"), but instead one should use various rewards ("the carrot") by actively informing people that there will be specific enticements for compliance;

5) Sustaining the new policy as well as controlling how well it works: in this regard, too, it helps to consult with local inhabitants and ask for additional suggestions on how to improve the approach taken.

In all this, local governments should involve more active means of communicating with the local community to keep the dialogue going.

In more theoretical terms the arguments for the benefits of public participation in all sorts of decision-making, but especially in local developmental planning, have been made by a variety of social scientists who are proponents of neoinstitutionalism and participatory democracy. Both theories argue that communal involvement and cooperation leads to better outcomes than if administrators decide by themselves. It is argued that due to the involvement of the citizenry, local plans and programs will be more attuned to local contexts, and local residents will be more supportive in implementing them, which is a precondition for any plan to succeed. Consultation and dialogue also allow for conflicting views and interests to be reconciled, or at least to be aired openly. This minimizes the likelihood of destructive protests.

Next to arriving at better solutions, societal involvement in public deliberations has the added role of shaping the views and behaviors of participants. In this regard the theoretical assumption is that the process of deliberation trains participants in various democratic practices such as analyzing the host of factors affecting a policy, and arguing the advantages of a certain approach. Advocates of neo-institutionalism argue that institutions and the procedures they employ shape the views and behavior of the people involved in contact with them, and therefore, new approaches in institutional arrangements and involvement can form new political cultures (Immergut, 1998, p. 21).

In sum, the basic argument in support of societal involvement in governance is that "the benefits of public participation processes include better decisions, better implementation, enhanced legitimacy, transparency, accountability trust and fairness for the government, better opportunities for learning, self-fulfillment and services of public policy for the wider public" (Mžavanadze, 2009, p. 401). 


\section{Forms of participatory decision-making}

In October 2009, an international NGO conference organized by the European Council outlined the basic principles of participatory democracy and confirmed a Code of Good Practice for Civil Participation in the Decision-Making Process. The code speaks of "shared spaces for dialogue and cooperation" (INGOs, 2009, p. 6) and at its core are several graphs that depict four levels of participation in the decision-making process according to intensity and quality. The suggestion is that these four modes of societal involvement should be implemented on all administrative levels of both executive and legislative bodies: information, consultation, dialogue and partnership (see Fig. 1). The lowest level of interaction is deemed to be 'Information', with the highest level defined as 'Partnership'.

Figure 1. The different levels of participation

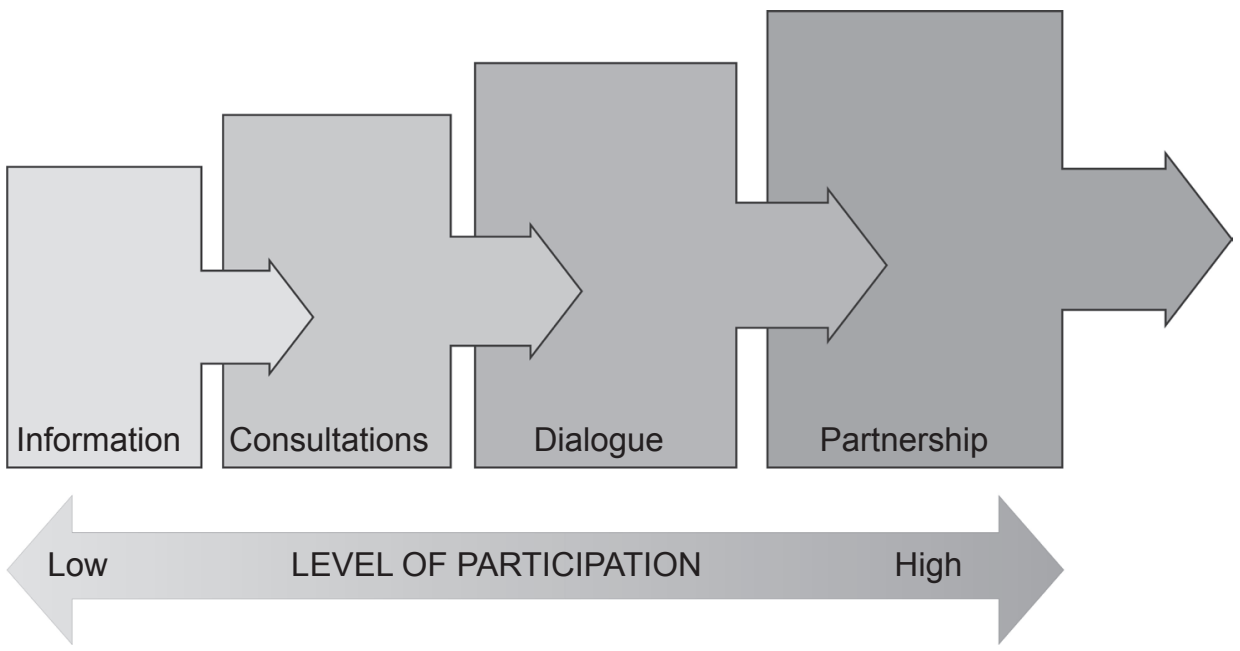

Source: INGOs, 2009

In this schema information is classified as the least significant level of participation because it tends to involve a one-directional flow of information from society to governing units, usually without a response. Yet, it is a form of participation, because administrators on their part have the duty to provide basic information to all sides concerned, including about possibilities of deeper involvement.

Consultations are seen to constitute an intermediary level of participation characterized by an official institution taking the initiative and giving a concerned non-governmental organization an opportunity to present its point of view and recommendations. In this situation there is a two-way flow of information and 
communication, but typically it is the administration side that picks the topics about which to consult with concerned groups. The organizations on their part provide their assessments and experience about a policy document or legislative proposal.

Dialogue constitutes an intermediary to high level of participation. In practice this means that there are formal public hearings by municipal, parliamentary, or governmental committees and the topic of discussion is substantial. The administrative partner organizes the place and time for the dialogue to take place, and the communal group on its part instigates or chairs the discussions, seminars, or conferences. Both sides take responsibility for summarizing suggestions and conclusions and following up on them.

Partnership constitutes an intense level of participation that is characterized by shared responsibility and duties between governing bodies and organized societal groups on all levels of decision-making. Partnership means more than intensive interaction in bodies that guarantee joint decision-making, since it also involves cooperation in the form of, for example, the delegations of certain functions to NGOs. Thus a non-governmental charity group may take on the task to provide care services for a socially weak group, such as handicapped persons. It could also mean implementing a part of the planned activities, for example by rural action groups implementing small projects. In all these cases, participation is seen as leading to empowerment of groups of citizens.

While the four categories of participation in decision-making outlined by the Code of Good Practice and illustrated in Figure 1 are helpful in clarifying forms and levels of influence by societal groups, in-depth research in Latvia, as well as analytical reflection, leads to several additional forms of how citizen groups can impact administrative and governmental decision-making. The additional four categories can similarly be depicted by level of influence on decision-making, as illustrated in Figure 2.

Protests can have a significant effect on the final administrative or governmental decision, if societal groups feel that their interests or points of view have been ignored, or are being violated, and they mobilize to express their nonconcurrence actively.

A similar, but analytically different form of participation is the initiation of legal action by a NGO or informal group of concerned citizens who challenge an administrative decision in court. In Latvia, this practice has been used increasingly often in recent years, but in order for it to have any chance of success, legal provisions that the claimants can base themselves on have to be in place. The legal suit can succeed only if it can refer to specific laws and regulations, 
or even to basic civic rights as outlined in the Constitution. Precedents of such legal challenges in Latvia show that suits also have a better chance of success if specific laws are in place about the right of citizens to participate in decisionmaking, for example about environmental concerns. Some examples will be cited below.

\section{Figure 2. Additional levels of participation}

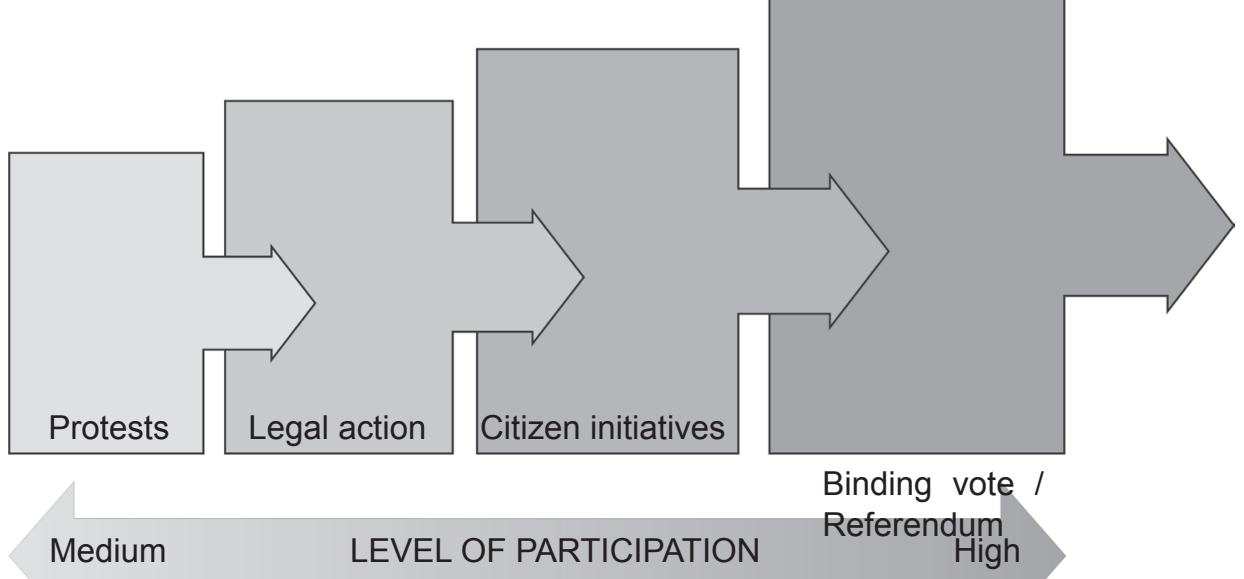

Citizen initiatives are institutionalized collective proposals to a decision-making body that have recently emerged as a new form of democratic participation in Latvia and the European Union. They are likely to become more significant in future years. In the case of Latvia, the legal framework for citizen initiatives on the national and EU level were put in place during the years 2011 to 2012, and it is likely that they will duplicated on the municipal level in the not too distant future.

Referenda are the most influential form of citizen participation in decisionmaking, as they in fact represent law-making itself. Latvia has one of the most extensive systems of popular referenda in the world; referenda can be triggered in seven distinct ways and citizens vote on a specific law, constitutional amendment, or the dissolution of parliament (Auers, Ruus \& Krupavicius, 2009, pp. 81-106). In recent years initiating a nation wide referendum has become an increasingly frequent and controversial practice in Latvia (see details below). 


\section{Popular participation in practice}

Overview. While significant forms of communal involvement in policy-making have been put in place in terms of procedural arrangements, one has to ask how well they work in practice. At this time the answer can be only be provisional, as most of the new arrangements have been put in place relatively recently. Yet, experience to date is rather promising.

A recent systematic survey of the non-governmental sector in Latvia found that forty-four per cent of NGO representatives are convinced that their organizations can influence decision-making, with those groups focusing on the common good showing a slightly higher rate. Organizations representing professionals or business people show the highest rate of positive assessments (89\%), followed by organizations that specifically focus on interest representation and legislative work (65\%), as well as environmental groups (62\%) (BISS, 2011, p. 40). Focus groups and personal interviews with NGO leaders show that cooperation takes place mostly with representatives of ministries by participating in working groups and consultative councils where departmental planning documents or drafts of laws are being prepared. NGO representatives are invited because they are seen to be better informed about the needs of the groups they represent, and can anticipate how one or the other approach might influence their field. Usually NGOs cooperate with the specific ministries that work on issues of interest to them, and close relations tend to develop over time (BISS, 2011, pp. 13-14).

Research on experiences with participation in decision-making at the municipal level shows that while citizens formally are able to take part in the general meetings of local councils, in practice the most productive way is to participate in meetings of committees and commissions. During deliberations in these smaller bodies societal groupings have the best chance to be heard in regard to issues that are of core interest to local residents, for example housing, various social services, and plans that would provide additional leisure activities. Constituents also take action to be heard when it appears important to stop a decision that has already been made, which most often happens in regard to a construction project (Šaka, 2009, pp. 6-10). In comparison to these generally optimistic findings of this study covering all of Latvia, another study, conducted in 2009 and focusing on municipalities in the Riga region, draws more modest conclusions about NGOs' impact on local council decision-making (Grigorjevs, Pīpiķe \& Šimanska, 2009). 


\section{Illustrative examples of civic participation}

Information. Access to information in Latvia is wide in scope on all levels of government. Ministries and numerous subordinated institutions have Internet homepages that provide extensive information about the specific institution, its functions and the services it provides. Interested persons can follow the process of drafting new legislative acts, starting with their being proposed at the State Secretaries' meeting until their adoption in the Cabinet of Ministers. Representatives of NGOs have the opportunity to participate in the meetings of state secretaries, and most cabinet meetings are open as well (Golubeva \& Reinholde, 2009, pp. 59-60).

Access to information is similarly broad in most municipalities. A survey of the web sites of all the municipal councils in the Kurzeme region showed that even the smaller counties have very informative web sites, where detailed announcements about meetings, events, and new policies are posted. ${ }^{2}$ As a rule, municipal leaders emphasize the importance of information and communication: one rural town in its 2011 annual report specifically defined comprehensive information as its main principle of civic participation:

The municipal council of Olaine makes certain that local residents are informed about its decisions, that they can express their views in due course, and receive extensive replies. In order to safeguard this, the council publishes an informative bulletin once a month and distributes five thousand copies free of charge (Hanovs, 2012, p. 177).

Consultations between governing institutions and residents take place in many different ways, which are party informal, partly formal. When municipal councils take the initiative they typically give a concerned non-governmental organization the opportunity to present its point of view and suggestions for some activity. Thus a study comparing societal participation in five rural towns with a significant ethnic minority population concluded that in the case of the most "participatory" town, Balvi, minority group involvement in policy-making consisted primarily of public forums and planning meetings about how to promote locally significant projects. As noted by a representative of the Russian cultural society: "each year in January we have a work seminar where all of us cultural activists deliberate on a activity plan for the year" (Hanovs, 2012, p. 123).

2 See, e.g., http://www.aizputesnovads.lv or http://www.dundaga.lv/avize/ d111_20110330.pdf [accessed 14 Oct 2012]. 
In addition to more formal modes of consultation with citizens there are indirect ways to explore their views, for example through sociological surveys. In the course of formulating local developmental plans, many rural councils have distributed questionnaires or conducted small surveys asking for ideas. The Latvian government on its part has sponsored numerous studies and surveys to determine how best to implement some policy, for example, it sponsored a study in the Latgale region that asked respondents about patterns of interaction with governmental and municipal service providers (SKDS, 2011).

Dialogue during mandatory public hearings. In Latvia and elsewhere in the European Union public hearings increasingly have become mandatory in regard to major governmental decisions, especially so about strategic development planning and territorial zoning. By law, consultations with society are required even at the highest level, such as during decision-making about Latvia's National Development Plan 2014-2010. During deliberations about this national plan in summer 2012 the governmental planners, working directly under the auspices of the Prime Minister, organized hearings in various regions of Latvia. They also provided opportunities for individuals and NGOs to voice their views at smaller meetings and in written form on a web site. This resulted in more than one thousand proposals (BNS, 2012). While not all proposals can be included in the official plan, they are carefully analyzed and taken account of where possible.

In Latvia's countryside, the involvement of the citizenry in decision-making on general development plans began on a mostly voluntary basis on the part of the official institutions involved, yet it has increasingly become mandatory as new national and EU regulations have been passed. As of 2011/2012 all municipalities have engaged local residents in the planning of mandatory development programs that have to be completed by 2013. Deliberations have taken different forms: there have been resident surveys, various types of public forums, and formal hearings organized by municipal councils. Experience with these events has varied. After analyzing these hearings in another part of the research project I have concluded that the outcome is much more favorable if the process is organized from the bottom up, by civic activists being in charge of agenda-setting and generating truly broad societal participation. To generate real proposals and discussion, and to avoid some more vocal people just letting off steam, trained moderators have to structure discussions in a purposeful way. People involve themselves more constructively if the discussions succeed in focusing on issues close to their hearts, such as cultural and social provisions (Kārkliṇa, 2012, pp. 67-87). 
Participatory success is less likely if meetings are organized by local officials and chaired in a formalistic manner, without a real generation of open discussion. A scholar who attended an official town meeting on territorial planning notes the "dogged formality of the event" (Ozolina, 2010, p. 581). Other studies have drawn similar conclusions, for example, if deliberations are too formal residents fail to get seriously involved. This is especially true in those cases where complicated and more technical issues are discussed, such as in regard to official territorial plans and formal impact on environment assessments. By national and EU law, municipalities are required to organize public hearings and to conduct an Environmental Impact Assessment in regard to the substance of territorial development plans as well as specific larger economic projects. This procedure has been applied in Latvia since 2004, and it requires public deliberations. To date, it appears that the purpose of these meetings is poorly understood in smaller rural communities, and is often conducted in a mostly formal manner (Pavasars, 2012).

The fact that Latvia allows a certain level of participation on the part of community representatives in strategic planning and policymaking has been positively remarked on in a comparative study with Lithuania. While the process in Lithuania has been comparatively closed, Latvia is more open towards the involvement of experts and societal groups in this regard (Mžavanadze, 2009, p. 403).

Partnership. The emergence of partnership organizations and local action groups - partly supported by the EU and external foundations - has been a particularly significant new development in fostering democratic participation in policy-making. While the central representative bodies of trade unions, business organizations, and municipalities have become recognized "social partners" in policy-making at the national level, including during budget deliberations, a similar concept has been implemented in the countryside. Here the partnership model has been introduced as a means of dealing with the complex problems of contemporary rural life and has been funded by a special 2.5 per cent earmark of the EU agricultural fund for the planning period 2007-2013. In Latvia's case this funding amounts to approximately twenty-five million euros and is popularly known as "the leader program," since its acronym is LEADER.

During the last decade, partnership organizations have been created in all regions of Latvia. These bodies join municipal institutions, business organizations, NGOs, and other interested parties in a single cooperative network. Its main purpose is to promote social dialogue among the various partners and to have them work jointly in formulating local development strategies as well as implementing concrete developmental projects. To promote the latter, smaller 
"action groups" are formed within the larger body. These groups compete among each other for project funding, which is granted on a competitive basis, thus promoting the skills of grant-writing. Partnerships have flourished all over Latvia and have implemented many projects that improve the quality of life in a particular community. In rural areas the sponsored projects tend to be youth centers, activities for young parents or pensioners, and similar things. ${ }^{3}$

The partnership groups in Latvia's rural areas are coordinated by a national umbrella organization, the Rural Forum of Latvia. Its goals are defined as:

\section{Aims \& Objectives: Promoting the sustainable development of Latvian rural territories; Strengthening civil society in rural territories, promoting local initiatives and cooperation; Representing interests of rural population on the national and international level; Cooperation with government, municipalities, NGOs, business persons and other institutions (Latvian Rural Forum, 2012).}

Since the initial forming of partnerships and local action groups in the early 2000s in the Latgale region, several scholars have studied these new forms of participation in the Latvian countryside. The social, economic, educational and environmental projects organized by local initiative groups are found to have been important for the improvement of rural livelihoods, as well as for the creation of new social capital and skills of communal cooperation (Tisenkopfs $\&$ Sumane, 2004; Zobena \& Paula, 2007). Partnerships not only promote handson local community projects, they also serve the purpose of bringing people together and generating social capital that can lead to new cooperation.

Protests. In recent years rural people in Latvia have been quite active in protesting against governmental and EU agricultural policies, as well as against specific policies applied at the local level. The protests tend to be spontaneous and reactive. Typically, people belatedly learn about a planned development that they object to and view as endangering their environment and quality of life. Interestingly, many of the recent protests and local outrage in rural areas have focused not just on a planned developmental project, but also on the process of how decisions were made. As mentioned above, during the last decade local communities have been encouraged to participate in decision-making about small and large development plans, and local people feel cheated when they discover that their input has been ignored or joint decisions have been circumvented.

3 Author's interview with leaders of the Latvian Rural Forum on 31 May 2010, and numerous media reports. 
The protests follow a certain pattern in how they develop: everything starts with some local activists discovering the "misconduct" of a local or national state institution. They then publish protest letters to officials in local newspapers and concurrently start collecting signatures on petitions demanding open meetings and discussions that would reverse the decision. The language of the protest statements tends to be highly emotional, accusatory, and aggressive. Pickets may ensue, or legal action, and in some cases a compromise is reached. Thus a partial compromise was reached in a case in regard to a large state owned forest in the Jaunpiebalga County where the state agency in charge had secretly started planning to cut down huge swaths of the forest without consulting the local community. When this was discovered, public protests followed, reaching a peak at a turbulent meeting of the local council. In this instance the outcome was a compromise as it was agreed that the tree-felling would be more conservative and that the state company would help repair local roads that were affected by the project. At other times no compromise follows and local residents may decide on legal action. ${ }^{4}$

Legal action. In a case in Rucava County, local residents reacted with protests after they discovered that the municipal council had surreptitiously granted a construction permit for erecting forty-one wind energy generators on their territory. The local farmers only learned about this when representatives of the investor approached them about using their particular parcels of land for the construction. At first 182 local inhabitants signed a protest writ addressed to the local municipality. When this was unsuccessful, twenty people turned to Latvia's Constitutional Court, and when that was unsuccessful, they filed a suit in the European Human Rights' court in Strasbourg (Grišāne, 2011). The final outcome is uncertain at the time of writing. Interestingly, this is not the only case when taking legal action has become a form of protest and civic involvement in Latvia and thus illustrates another dimension of contemporary civil activism.

As mentioned, citizen initiatives are formal collective proposals that serve as a new form of citizen involvement in policy-making. Procedurally, they require that a specific proposal about a new law or policy be signed by a specific number of supporters and after that the proposal is reviewed by a decision-making body, which decides whether to proceed with an activity of its own. In fall 2011, Latvia's Saeima made a provision in its Rules of Order that the parliament will review, according to specific procedures, proposals that have been signed by a group of at least ten thousand citizens. Similarly, since April 2012 the Commission of the European Union has introduced a new procedure according

$4 \quad$ Author's interviews and local media reports from 2010 to 2012. 
to which it will review EU citizen initiatives that have been signed by a total of one million citizens in at least seven different EU countries. The number of required signatures is determined according to the size of population in specific countries, in Latvia's case six thousand signatures are required (Council of the EU, 2012). In contrast to referenda, "citizen initiatives" only trigger the review of a proposed policy or law; they do not represent direct democracy in the sense of law-making itself.

Referenda. In recent years the initiation of a nationwide referendum has become an increasingly frequent, and increasingly controversial, practice in Latvia. The controversy is due to referenda being expensive, but also due to a variety of other issues. One issue concerns the percentage of citizens who have to sign when a group of citizens starts gathering signatures in support of an amendment to a law or the constitution. To date the initiative group is required to secure only ten thousand signatures, which constitutes less than one percent of the voting public. Nevertheless, once the Election Board of Latvia verifies the original ten thousand signatures, it is obligated to organize and pay for the institutional framework for gathering additional signatures in support of the proposal. If one-tenth of citizens sign during this second stage of signature gathering, a formal referendum follows. Experience shows that many such referenda are unsuccessful and mostly serve to raise the electoral visibility of a particular political party (Auers, 2012).

Another controversy surrounds the issue that while an affirmative referendum outcome constitutes the passing of a concrete law or constitutional change, there currently is no way to review the substance and technical quality of proposals. Since more and more referenda measures are being proposed, the need for procedures about a review of their textual and legal quality has become urgent. As a result, Latvia's parliament, legal experts, and the Constitutional Court have started deliberating on the issues since early 2012 and the discussion is continuing. One especially crucial question is whether the "constitutional core" of Latvia's democracy can be the object of a referendum, and what institution should have the authority to review proposed initiatives.

The question about an inviolable constitutional core arose in February 2012 when a referendum was held on a proposal to change Latvia's constitution and adopt Russian as a second official state language, on equal footing with Latvian, the current official state language. Once the referendum was held voter participation was exceptionally high (ca. 70\%) and this radical constitutional change was rejected. Votes clearly broke on ethnic and linguistic lines, with the tally closely mirroring the breakdown of Latvian and Russian speakers: nearly 
75 per cent, or 821,722 people, opposed the referendum, while 25 per cent of voters were in favor (Herszenhorn, 2012). Parallel to ongoing deliberations about the content and procedures for nation-wide referenda, discussions have been underway about the possibility of instituting referenda on the municipal level. The proposed law about referenda at the municipal level could allow those about the ouster of local councils, about major infrastructure projects, long term development strategies and procedural issues linked to these.

\section{Conclusion}

Latvia has followed the recent trend in most contemporary societies of citizens becoming increasingly distrustful of representative democracy and traditional political activities such as voting and involvement in political parties, trade unions, and classic civic associations. However, it is misleading to see citizen participation as declining, instead, one should take account of new forms of participation that focus on developing influence through horizontal interaction between different societal groupings, including between non-governmental organizations and official political players such as political parties, and elective and governmental institutions. In Latvia's case there is a strong trend towards the involvement of "social partners" and the forming of partnerships and consultative councils to ministries, municipal councils, and other institutions. The basic goal is to enhance social dialogue and communal self governance, with the assumption being that this improves official decisions and policy formation.

The rationale for societal group involvement in governance decisions has been formulated in various ways. The core assumption is that participation leads to better decisions and better governmental implementation. This article has presented the main modes of this participation: information, various forms of deliberation, dialogue and consultation, partnerships and protests, citizen initiatives and referenda. Among the various public participation processes instituted in Latvia's countryside, consultative hearings about the goals of local development programs and territorial zoning have been especially comprehensive. 


\section{References}

Auers, D. (2012), 'An Electoral tactic? Citizens' Initiatives in Post-Soviet Latvia,' in M. Setala \& T. Schiller (eds.) Citizens' Initiatives in Europe: Procedure and Consequences of Agenda-Setting by Citizens, London: Palgrave Macmillan, pp. 53-68.

Auers, D.; Ruus, J. \& Krupavicius, D. A. (2009), 'Financing Referendums and Initiatives in the Baltic States,' in K. G. Lutz \& S. Hug (eds.) Financing Referendum Campaigns, London: Palgrave Macmillan, pp. 81-106.

Beissinger, M. R. (2002), Nationalist Mobilization and the Collapse of the Soviet State, Cambridge: Cambridge University Press.

BISS (2011), Pārskats par NVO sektoru Latvijā [The NGO sector in Latvia], Riga: Baltic Institute of Social Sciences.

BNS (2012), Par NAP saņem tūkstoti priekšlikumu: galīgo versiju sola līdz oktobra beigām [The NDP gets a thousand proposals: the final version promised by the end of October], Delfi.lv, 21 September 2012.

Council Regulation (2011) Council Regulation 211/2011/ of the European Parliament and of the Council of 16 February 2011 on the Citizens' Initiative, Official Journal of the European Union, L 65, 11.03.2011, pp. 1-22.

Golubeva, M. \& Reinholde, I. (2009), 'Efficiency and Accountability of Governance Structures,' in J. Rozenvalds (ed.) How Democratic is Latvia: Monitoring of Democracy 2005-2007, Riga: Zinātne, pp. 53-61.

Greenberg, J. (2010), “"There's Nothing Anyone Can Do About It”: Participation, Apathy, and "Successful” Democratic Transition in Postsocialist Serbia,' Slavic Review, vol. 69, no. 1, pp. 41-64.

Grigorjevs, E.; Pīpiķe, R. \& Šimanska, I. (2009), Pašvaldību un nevalstisko organizāciju sadarbība kopienai R̄̄gas reǵionā [Communal cooperation between nongovernmental organizations and municipalities in the Riga region], Riga: Latvijas Pilsoniskā alianse.

Grišāne, A. (2011), 'Dunikas vēju sāga' [Wind saga in Dunika], Politika.lv. Retrieved from http://www.politika.lv/temas/tiesiska_valsts_un_korupcija/18959/ [accessed 15 April 2012]

Hanovs, D. (2012), Latvijas reǵionu mazo pašvaldību stratēgijas dažādības vadībā [Integration policies in Latvia’s small municipalities], Riga: Turība.

Herszenhorn, D. M. (2012), 'Latvians Reject Russian as Second Language,' The New York Times, 19 February 2012.

Hoskins, B.; Abs, H.; Han, C.; Kerr, D. \& Veugelers, W. (2012), Contextual Analysis Report: Participatory Citizenship in the European Union. Retrieved from http:// ec.europa.eu/citizenship/pdf/report_1_conextual_report.pdf [accessed 20 Jun 2012] 
Immergut, E. N. (1998), 'The Theoretical Core of the New Institutionalism,' Politics \& Society, vol. 26, no. 1, pp. 5-34.

INGOs (2009), Code of Good Practice for Civil Participation in the Decision-Making Process, Strasbourg: Conference of INGOs of the Council of Europe. Retrieved from http://www.coe.int/t/ngo/Source/Code_English_final.pdf [accessed 5 Oct 2012].

Kārkliņa, R. (2012), 'Lauku kopienu, pasvaldību un valsts iestāzu sadarbiba attīstības planošanā' [Cooperation of communities, municipalities and the state in developmental planning], in A. Cimdiņa \& I. Raubiško (eds.) Dzīve - AttīstībaLabbūtība Latvijas, Riga: Zinātne, pp. 67-87.

Karklins, R. (1994), Ethnopolitics and Transition to Democracy: The Collapse of the USSR and Latvia, Baltimore: Johns Hopkins University Press.

Karklins, R. \& Zepa, B. (2001), 'Political Participation in Latvia 1989-2001,' Journal of Baltic Studies, vol. 32, no. 4, pp. 334-346.

Krek, J.; Losito, B.; Ridley, R. \& Hoskins, B.; (2012), Good Practices Report: Participatory Citizenship in the European Union. Retrieved from http://ec.europa. eu/citizenship/pdf/report_3_good_practice.pdf [accessed 20 Jun 2012].

LPS (2009), 'Pašvaldības deputātu rokasgrāmata' [Handbook for municipal officials], Logs, Jul/Aug, Rīga: Latvijas Pašvaldību savienība.

Mžavanadze, N. (2009), 'Sustainable Development in Lithuania: Between the Government Agenda and the Undiscovered Civil Society,' Journal of Baltic Studies, vol. 40, no. 3, pp. 397-414.

National "Latvian Rural Forum" (2012), [Home page] Retrieved from http://www. elard.eu/elard/national-leader-networks/en_GB/national-latvian-rural-forum [accessed 14 Oct 2012].

Norris, P., ed. (1999), Critical Citizens: Global Support for Democratic Government, New York: Oxford University Press.

Ozolinga, L. (2010), 'Raspberries, Tablecloths, and Critical Thinking: Accountability Reforms in Post-Socialist Latvia,' East European Politics and Societies, vol. 24, no. 4, pp. 572-594.

Pavasars, I. (2012), 'Stratēgiskais ietekmes uz vidi novērtējums lauku pagastos' [Environmental Impact assessment in Rural Municipalities], in A. Cimdiña \& I. Raubiško (eds.) Dzīve - Attīstība - Labbūtība Latvijas laukos, Riga: Zinātne, pp. 118-134.

Petrova, T. \& Tarrow, S. (2007), 'Transactional and Participatory Activism in the Emerging European Polity: The Puzzle of East-Central Europe,' Comparative Political Studies, vol. 40, no. 1, pp. 74-94.

Rieksta, S. (2010), Nevalstisko organizāciju lìdzdalība valsts pārvaldes darbībāa, problèmas un risinājumi [The participation of nongovernmental organizations in the public administration, problems and solutions], M.A. thesis, Riga: University of Latvia. 
Šaka, A. (2009), 'Interešu grupu un pašvaldību sadarbības tendences: Daugavpils, Jelgavas, Valmieras un Ventspils pašvaldību analīze' [Cooperation between municipalities and interest groups: analysis of the Daugavpils, Jelgava and Valmiera municipalities], Alternatīva, pp. 2-10.

Sedlenieks, K. (2012), 'Dz̄ive valsts kabatās. Apzināta izvairīšanās no valsts kā izdzīvošanas (attīstības) stratēgijas Latvijas laukos' [Life in the "Voids of the State": Deliberate avoidance of state as a survival (development) strategy in the Latvian countryside], in A. Cimdiņa \& I. Raubiško (eds.), Dzīve - Attīstība Labbūtība Latvijas laukos, Riga: Zinātne, pp. 88-117.

SKDS (2011), Attieksme pret pašvaldību un Vienas pieturas aǵentūrām [Attitudes toward municipal one-stop agencies], Daugavpils: SKDS \& Publiskās pārvaldes konsultācijas \& A-Sono. Retrieved from http://www.lsif.lv/nodevumi/ nodevumi/3211/Aptauja_Latgale_iedzivotaji.pdf [accessed 10 Aug 2012].

Tisenkopfs, T. \& Sumane, S. (2004), 'Rural Community Initiatives in the Latvian Countryside,' in I. Alanen (ed.) Mapping the Rural Problem in the Baltic, Aldershot: Ashgate, pp. 219-247.

Yaojun, L. \& Marsh, D. (2008), 'New Forms of Political Participation: Searching for Expert Citizens and Everyday Makers,'British Journal of Political Science, no. 38, pp. 247-272.

Zobena, A. \& Paula, L. (2007), 'Partnerība - inovatīvs diskurss Latvijas lauku attīstībā,' [Partnership - an innovative discourse for the development of Latvia's countryside] Sociologija, no. 714, Riga: University of Latvia, pp. 72-85. 